\title{
THE
}

\section{Examination of Ulva bloom species richness and relative abundance reveals two cryptically co- occurring bloom species in Narragansett Bay, Rhode Island}

Michele Guidone

Carol S. Thornber

University of Rhode Island, thornber@uri.edu

Follow this and additional works at: https://digitalcommons.uri.edu/bio_facpubs

Terms of Use

All rights reserved under copyright.

\section{Citation/Publisher Attribution}

Michele Guidone, Carol S. Thornber, Examination of Ulva bloom species richness and relative abundance reveals two cryptically co-occurring bloom species in Narragansett Bay, Rhode Island. Harmful Algae, 24, April 2013, Pages 1-9.

Available at: http://dx.doi.org/10.1016/j.hal.2012.12.007

This Article is brought to you for free and open access by the Biological Sciences at DigitalCommons@URI. It has been accepted for inclusion in Biological Sciences Faculty Publications by an authorized administrator of DigitalCommons@URI. For more information, please contact digitalcommons-group@uri.edu. 
2

3 Examination of Ulva bloom species richness and relative abundance reveals two cryptically cooccurring bloom species in Narragansett Bay, Rhode Island

5

$8{ }^{1}$ University of Rhode Island, Department of Biological Sciences, 120 Flagg Road, Kingston, RI, USA 02881

$10{ }^{2}$ Current address: Sacred Heart University, Biology Department, 5151 Park Avenue, Fairfield,

* Corresponding author: guidonem@sacredheart.edu 


\section{Abstract}

Blooms caused by the green macroalga Ulva pose a serious threat to coastal ecosystems around the world. Despite numerous studies of the causes and consequences of these blooms, we

21 still have a limited understanding of Ulva bloom species richness and abundance due to

22 difficulties in identifying Ulva species using morphological features. Along the northeastern U.S. 23 coastline, all blooms of distromatic Ulva blades were previously identified as U. lactuca. Recent 24 molecular sequencing, however, discovered the presence of additional distromatic Ulva species.

25 Therefore, in order to determine the relative abundance of Ulva species within blooms, we 26 conducted monthly surveys at four Narragansett Bay, RI, sites representing a gradient of bloom

27 severity. We found that the biomass of Ulva within blooms was a mix of $U$. compressa and $U$.

28 rigida, not $U$. lactuca as previously reported. In contrast, sites not impacted by blooms that were 29 located near the mouth of Narragansett Bay were dominated by U. lactuca. We also observed 30 spatial and temporal differences in Ulva and total macroalgal diversity between bloom-impacted 31 sites, indicating that Ulva bloom composition can be radically different between similar sites 32 within close proximity. We discuss our results in the context of Ulva blooms worldwide, 33 highlighting the need to definitively determine bloom species composition in order to fully 34 understand bloom dynamics.

36 Key words: biomass, diversity, eutrophication, macroalgal bloom, survey, Ulva

\section{Introduction}

The formation of blooms of filamentous and/or thin foliose macroalgae are frequently a 40 consequence of coastal eutrophication (Fletcher, 1996; Valiela et al., 1997; Morand and 
41 Merceron, 2005; Ye et al., 2011). Macroalgae with these morphologies have a high surface area

42 to volume ratio that enables them to rapidly uptake nutrients for greatly increased growth (Littler

43 and Littler, 1980; Hein et al., 1995; Pedersen and Borum, 1996), provided favorable bathymetric,

44 temperature, and light conditions exist (Rivers and Peckol, 1995; Taylor et al., 2001; Cohen and

45 Fong, 2004; Sousa et al., 2007; Liu et al., 2010).

46 Bloom macroalgae often form large floating mats in the water column, in which

47 individual thalli grow, fragment, and asexually reproduce via zoospores (Gao et al., 2010; Ye et

48 al., 2011). These floating mats of algae alter coastal light, nutrient, and water flow conditions,

49 causing decreases in perennial algae, seagrasses, and benthic invertebrates (Valiela et al., 1997;

50 Hauxwell et al., 1998, 2001; Thomsen and McGlathery, 2006; Worm and Lotze, 2006). Nightly

51 respiration and decomposition of bloom macroalgae contribute to hypoxic events (Valiela et al.,

52 1997; Raffaelli et al., 1998) that can result in substantial mortality of invertebrates and fishes

53 (Deacutis et al., 2006; Berezina et al., 2007). In addition, several species produce toxins that

54 negatively impact co-occurring organisms (Nelson et al., 2003a; Eklund et al., 2005; Van

55 Alstyne et al., 2006). Moreover, blooms interfere with coastal commercial and recreational

56 activities (Lee and Olsen, 1985; Thomsen and McGlathery, 2006; Deacutis, 2008; Leliaert et al., 57 2009).

58 Bloom-forming macroalgal species can be found within the phyla Chlorophyta,

59 Heterokontophyta, and Rhodophyta, but most macroalgal blooms, including the largest ever

60 recorded, are caused by Chlorophyta species, such as those within the genus Ulva Linnaeus

61 (Fletcher, 1996; Valiela et al., 1997; Morand and Merceron, 2005). For example, the 2008 bloom

62 of Ulva prolifera offshore of Qingdao, China contained an estimated 20 million wet tons of algae

63 spanning approximately $13,000 \mathrm{~km}^{2}$ in the Yellow Sea. This bloom required the removal of more 
64 than 1 million tons of $U$. prolifera from the shoreline, at a cost of over $\$ 100$ million US dollars

65 (Leliaert et al., 2009; Gao et al., 2010).

66 Ulva species are notoriously difficult to identify due to a lack of distinguishing

67 morphological features among species and a tremendous degree of phenotypic plasticity within

68 species (Blomster et al., 1999; Blomster et al., 2002; Leskinen et al., 2004). Until recently, this

69 morphological uncertainty hindered our ability to accurately assess species richness within Ulva

70 blooms. In the last decade, however, numerous molecular studies from bloom and non-bloom

71 impacted habitats around the world have greatly increased our understanding of Ulva richness

72 (e.g. Hayden et al., 2003; Leliaert et al., 2009; Kraft et al., 2010; Liu et al., 2010). However,

73 detailed surveys of the relative abundance of different Ulva species, as well as physiological and

74 ecological studies utilizing molecularly confirmed Ulva species, remain lacking (but see Liu et

75 al., 2010; Yokoyama and Ishihi, 2010; Kim et al., 2011). These knowledge gaps pose a serious

76 barrier in our ability to understand Ulva bloom dynamics, and consequently hinder the

77 development of macroalgal bloom risk assessments and well-informed coastal management

78 practices.

79 We conducted extensive surveys at four Narragansett Bay, Rhode Island sites (Figure 1),

80 to determine: 1) which Ulva species is (are) the main contributor(s) to Ulva blooms in

81 Narragansett Bay; 2) if bloom-forming Ulva species are found throughout Narragansett Bay or

82 only in bloom-impacted areas; and 3) how the species richness and relative abundance of all

83 macroalgal species varies amongst bloom and non-bloom sites. We discuss our results in the

84 context of previously studied Ulva bloom systems and highlight the importance of determining

85 their species composition for understanding bloom dynamics. 
87

\section{Methods}

\subsection{Study locale and species}

Narragansett Bay is a well-studied estuary in which annual blooms of distromatic Ulva blades and, less often, monostromatic tubular Ulva spp. (formerly Enteromorpha, Hayden et al., 2003) and Gracilaria spp. occur in the anthropogenically impacted northern portions of the bay (Granger et al., 2000; Calabretta and Oviatt, 2008; Deacutis, 2008; Oczkowski et al., 2008; Thornber and Guidone, unpublished data). While tubular Ulva species in Rhode Island cannot be identified to the species level based on morphological features alone, significant progress has been made in distinguishing between Ulva blades in this region. Originally identified as monospecific blooms of $U$. lactuca, molecular sequencing of Ulva blades within Narragansett Bay and along the outer Rhode Island coast detected three species of Ulva blades: $U$. compressa Linnaeus, U. lactuca Linnaeus, and U. rigida C. Agardh (Guidone et al., unpublished data). Similar results were found in molecular assessments of Ulva in the Great Bay Estuarine System in New Hampshire and Maine (Hofmann et al. 2010). These blade-forming species can be reliably distinguished based on a suite of cellular features including cell size, shape, and arrangement, chloroplast position, and pyrenoid number (Guidone et al., unpublished data; Hofmann et al., 2010).

\subsection{Survey methodology}

We first assessed the biomass of Ulva compressa, U. lactuca, and U. rigida, and the percent cover of all algal species throughout Narragansett Bay by conducting monthly surveys from May-September 2009 at four field sites: Brushneck Cove and Chepiwanoxet, Warwick, RI and The Graduate School of Oceanography (GSO) and Pier 5, Narragansett, RI (Figure 1). 
110 Brushneck Cove and Chepiwanoxet are located in Greenwich Bay, a subestuary of Narragansett

111 Bay that experiences annual Ulva blooms (Granger et al., 2000; Thornber and Guidone,

112 unpublished data). Both Brushneck Cove and Chepiwanoxet are intertidal mud flats bordered by

113 fringing salt marshes; however, Chepiwanoxet has a longer water residence time (1.5 days versus

1140.3 days), a greater mean depth, and experiences lower temperatures and a greater incidence of

115 hypoxic events (Granger et al., 2000; Thornber and Guidone, unpublished data). These sites were

116 contrasted to GSO and Pier 5 (Figure 1), which are near the mouth of Narragansett Bay and are

117 not impacted by annual Ulva blooms. GSO is a narrow beach of mixed sand and cobblestone,

118 while Pier 5 is a boulder field.

119 For comparison across seasons, additional surveys were conducted in February and May

1202010 at all four sites. Monthly surveys were subsequently continued at the two bloom-impacted

121 sites from June 2010 to November 2011.

122 We conducted all surveys during spring low tides. For each survey, at each site, we

123 placed two $10 \mathrm{~m}$ transects parallel to the shore; transects were at least $30 \mathrm{~m}$ apart and placed at

124 the same tidal height. Transect positioning corresponded to the tidal height where Ulva wrack

125 was most commonly observed at low tide; this was directly below the fringing marsh at

126 Brushneck Cove and Chepiwanoxet, and directly above the waterline at GSO and Pier 5. For our

127 initial May-September surveys, we used a $0.25 \mathrm{~m}^{2}$ quadrat to calculate the percent cover of all

128 algal taxa at one meter intervals along each transect, for a total of twenty replicate samples per

129 site and sampling month. Subsequent surveys assessed percent cover at two-meter intervals, for a

130 total of ten replicate samples per site and sampling month. Due to the overlap of macroalgal

131 thalli within drift mats, the total percent cover of all species often totaled more than $100 \%$. Algae

132 were identified to the lowest taxonomic unit possible in the field. The Ulva blades within each 
133 quadrat were collected and returned to the laboratory. Additionally, beginning in February 2010

134 we collected Ulva tubes from the bloom-impacted sites for biomass comparison to Ulva blades.

135 In the laboratory, we identified each blade to species using distinguishing cellular features

136 determined from molecularly confirmed voucher specimens (Guidone et al., unpublished data).

137 Following identification, blades were spun to a constant weight using a salad spinner and then

138 weighed.

2.3 Statistical analyses

141 We analyzed Ulva bloom biomass data for our 2009-2010 survey and our bloom-

142 impacted sties (2010-2011) using fully factorial nested ANOVAs with fixed factors for month-

143 year, site, species, and transect nested within site (JMP, version 8, SAS Institute Inc., North

144 Carolina, USA). We were unable to normalize our data via transformation, however the analysis

145 of variance test is robust to departures from normality and homogeneity of variances when

146 datasets are large. In this instance, our datasets were sufficiently large to ensure that our results

147 were not impacted by violating these assumptions (Underwood, 1997).

148 Percent cover data for our 2009-2010 and 2010-2011 surveys were used to calculate the

149 average Shannon-diversity index (H') and Pielou's evenness (J') for each site. Additionally, algal

150 percent cover was assessed for differences in taxa among sites and sampling months using a two-

151 way crossed analysis of similarity (ANOSIM). The contribution of each taxon to the average

152 similarity and dissimilarity among sites and months was determined using a similarity of

153 percentages analysis (SIMPER). Prior to ANOSIM and SIMPER analysis, data were fourth-root

154 transformed to increase the importance of rare species; all analyses were conducted on Bray- 
155 Curtis similarities. Non-parametric analyses were conducted using Primer-E (version 6, Primer-E 156 Ltd., Plymouth UK).

157

158 3. Results

159 3.1. Ulva species richness and relative abundance

160 Ulva lactuca was the dominant blade forming Ulva species at non-bloom sites, while $U$.

161 compressa and $U$. rigida dominated at bloom sites. Overall, Ulva species biomass varied

162 significantly amongst sites and months (Table 1). In 2009-2010, U. lactuca was the only blade

163 species found at the non-bloom impacted Pier 5, with peak mean wet biomass of $75.48 \mathrm{~g} / \mathrm{m}^{2}$ in

164 May 2010 (Figure 2a). Ulva lactuca also dominated at GSO, where we only found small

165 fragments $(<0.4$ g per piece) of $U$. compressa and $U$. rigida during three of the seven survey

166 months (Figure 2b).

167 In contrast, over the entire course of this study (2009-2011), U. lactuca was rarely found

168 at either of our bloom-impacted sites, while U. compressa and $U$. rigida were consistently

169 present at both sites (Figure 3). The mean Ulva biomass was significantly greater at Brushneck

170 Cove than the other three sites during 2009-2010 (Tukey post-hoc test, $\mathrm{p}<0.05$ ); there was no

171 significant difference in biomass between Brushneck Cove and Chepiwanoxet in 2010-2011

172 (Table 1b). Additionally, while we observed no impact of transect placement during our 2009-

1732010 surveys, transect did have a significant impact on biomass at our bloom sites during 2010-

1742011 (Table 1).

175 At both bloom-impacted sites, biomass consistently peaked during June-July with

176 subsequent crashes in August (Figure 3). One exception to this pattern occurred during 2009 at

177 Brushneck Cove, which saw continued high biomass through September 2009 (Figure 3b). Total 
178 mean wet biomass was greatest during June $2009\left(882.80 \mathrm{~g} / \mathrm{m}^{2}\right.$; maximum observation $1,662.24$

$\left.179 \mathrm{~g} / \mathrm{m}^{2}\right)$ at Brushneck Cove and July $2010\left(665.88 \mathrm{~g} / \mathrm{m}^{2}\right.$; maximum observation 1,804.60 g/m $\left.\mathrm{m}^{2}\right)$ at

180 Chepiwanoxet.

181 Throughout our surveys from 2009-2011, U. compressa was nearly always the largest

182 component of Ulva mats at Chepiwanoxet, except during April 2011, May of each year, and

183 Sept. 2009, when Ulva tubes dominated (Figures 3-5). By contrast, U. rigida biomass was

184 greater than $U$. compressa during 2009 and 2010 at Brushneck Cove, while summer peaks in

185 June and July 2011 were dominated by U. compressa. Low densities of tubular Ulva species

186 were only present at Brushneck Cove during May of each year and April 2011 (Figures 3-5).

187 Despite having reliable morphological descriptions for our three targeted Ulva species,

188 we were occasionally ( $<12 \%$ of samples) unable to identify Ulva blades to species level.

189 Unidentifiable blades were more frequently encountered at Brushneck Cove and were more

190 abundant during the spring months (Figure 3).

191

192 3.2. Total macroalgal species richness and abundance

193 3.2.1. 2009-2010 survey

194 A total of 34 taxonomic groups were observed throughout our 2009-2010 surveys (Figure

195 4, Table 2). Species diversity (Shannon $\mathrm{H}^{\prime}$ ) was highest at non-bloom Pier 5 and lowest at

196 bloom-impacted Brushneck Cove (Table 3; one-way ANOVA F $3,456=91.40, \mathrm{p}<0.0001$, Tukey

197 post-hoc $\mathrm{p}<0.05)$. However, no clear correlation between bloom-impacted and non-impacted

198 sites was evident, as diversity was higher at bloom-impacted Chepiwanoxet than at GSO. In

199 addition, evenness (Pielou's J') was highest at Chepiwanoxet. Of the 34 taxa recorded, 22 were

200 found at only one or both of the lower-bay sites (Table 2). No individual taxa were unique to the 
201 two bloom-impacted sites; however, Chepiwanoxet was the only site that contained mats of

202 intertwined Agardhiella subulata, Ceramium virgatum, Gracilaria spp., and Polysiphonia spp.

203 (hereafter ACGP mats). While these mats could reach greater than 50\% cover, the thalli within

204 them were often small fragments, making separation of the component species impracticable.

205 Therefore, we considered these mats as a unique entity for this study.

206 Taxon assemblages were significantly different amongst all sites and sampling months

207 (ANOSIM, $p=0.001$; Table 4). In concurrence with the Shannon diversity index, the largest

208 difference in algal composition was observed between bloom-impacted Brushneck Cove and

209 non-bloom Pier 5 (Table 4a), while the smallest difference was between bloom-impacted

210 Chepiwanoxet and non-bloom GSO. However, the high R-value and significance $(\mathrm{p}=0.001)$ of

211 all pairwise tests between sites indicates strong separation of algal communities among all sites

212 (Table 4a). Differences in algal composition between the bloom and non-bloom impacted sites

213 were largely due to the greater percent cover of Ulva blades at the bloom impacted sites and the

214 presence of Chondrus crispus at the non-bloom sites (Figure 4, Table 5). In addition, while Ulva

215 tubes were found at all four sites, their occurrence and percent cover varied temporally (Figure 4,

216 Table 5).

217 Amongst months, the largest differences in flora were between February and August; the

218 smallest differences were between July and August (Table 4b). Seasonal shifts in algal

219 composition were apparent from June to July, August to September, and September to February

220 (Figure 4, Table 4b).

221

222 3.2.2. 2010-2011 survey of bloom-impacted sites 
As in the 2009-2010 survey, algal composition from June 2010-November 2011 differed

224 significantly between the two bloom-impacted sites (ANOSIM global $\mathrm{R}=0.272, \mathrm{p}=0.001$ ),

225 with a greater diversity at Chepiwanoxet than at Brushneck Cove (Table 3). The dominant taxa at

226 both sites were also similar to 2009-2010, with Ulva blades dominating the algal community at

227 Brushneck Cove during all months except January-May 2011; Ulva blades, Ulva tubes, and

228 ACGP mats dominated at Chepiwanoxet (Figures 4, 5, Table 2). Taxa observed in 2010-2011

229 that were not previously observed during 2009-2010 included Ectocarpus spp., Porphyra spp.,

230 Cladophora spp., and Scytosiphon lomentaria (Table 2).

231

232 4. Discussion

233 4.1. Ulva in Narragansett Bay

234 4.1.1. Species distribution

235 Our results demonstrate that $U$. compressa and U. rigida are responsible for the blooms

236 of Ulva blades in the northern portions of Narragansett Bay, RI. Neither of these bloom-forming

237 species was found at Pier 5, our field site closest to the open coast. In contrast, U. lactuca was

238 regularly observed at the two non-bloom sites near the mouth of Narragansett Bay and rarely

239 found at the bloom-impacted sites.

240 In a molecular assessment of Ulva species within the Great Bay Estuarine System of New

241 Hampshire and Maine, USA, Hofmann et al. (2010) found a similar distributional pattern for

242 these three species, with U. compressa and U. rigida typically occurring together at inner

243 estuarine sites and $U$. lactuca, along with U. pertusa, occurring at higher salinity sites closer to

244 the open coast. Their results, in conjunction with our own, suggest that U. compressa and $U$.

245 rigida are more physiologically and/or ecologically similar to each other than either is to $U$. 
246 lactuca. Based on the distributional pattern of these species in Narragansett Bay and the Great

247 Bay Estuarine System, we hypothesize that $U$. lactuca is rarely found in northern Narragansett

248 Bay bloom-impacted sites due to a lower tolerance of high water temperatures, salinity

249 fluctuations, and/or hypoxia or other factors. Likewise, if $U$. compressa and $U$. rigida are

250 adapted to the abiotic conditions found in shallow, low-flow eutrophic estuaries, they might be

251 absent from open coastal areas due to nutrient limitations or intolerance to higher salinities or

252 wave exposure.

253 One alternate explanation exists for the distributional pattern of U. compressa. Tan et al.

254 (1999) observed that distromatic blades of $U$. compressa were concentrated in low salinity areas

255 of an estuary in Aberdeenshire, Scotland, while U. compressa with a tubular morphology was

256 found at higher salinity sites near the North Sea. Taking this into consideration, it is possible that

$257 U$. compressa in Narragansett Bay persists in lower salinity eutrophic areas as a distromatic

258 blade and is present at lower bay and outer coast sites as a monostromatic tube. Although we did

259 not identify tubular Ulva to species in this survey, prior molecular analysis of outer coast

260 samples supports this hypothesis (Guidone et al., unpublished data).

261 In addition to abiotic factors, Ulva species distribution may be restricted by differences in

262 Ulva palatability and/or herbivore communities amongst the study sites. Nelson et al. (2008)

263 found that Ulva and Ulvaria (both in the family Ulvaceae) differed in abiotic tolerances and

264 palatability, causing the more palatable but stress tolerant Ulva to dominate intertidally while the

265 unpalatable Ulvaria thrived in the herbivore populated subtidal. Similarly, blooms in the Baltic

266 Sea were dominated by the unpalatable Pilayella littoralis when herbivores were abundant and

267 the palatable Ulva intestinalis when herbivores were absent or nutrient levels were enriched

268 (Lotze et al., 2000; Lotze and Worm, 2000). Although not directly quantified in this study, based 
269 on previous studies and our own field observations, herbivore communities between our bloom

270 and non-bloom sites can be substantially different (Guidone et al., unpublished data).

271

272

\subsubsection{Bloom species relative abundance}

273

While similar densities of Ulva were found at both bloom-impacted sites during the

summers of 2010 and 2011, the relative abundance of each Ulva blade species, as well as the

275

proportion of tubular Ulva species present, differed significantly. These spatial and temporal

276

fluctuations indicate that even between eutrophic sites within close proximity (only $3.5 \mathrm{~km}$

277

apart), small abiotic or biotic differences, or stochasticity, may lead to markedly different Ulva

278

bloom compositions. Nelson et al. (2003b) observed similar patterns amongst Ulva blades, Ulva

279

tubes, and Ulvaria, on a slightly larger scale in the Pacific Northwest. Our observation that Ulva

280

biomass differed amongst transects during 2010-2011 indicates that temporal changes in water

281 flow and/or wind patterns may play an important role in Ulva bloom deposition patterns in the

282 intertidal.

283

284

4.2. Total macroalgal diversity at bloom and non-bloom sites

285

As we had expected, Pier 5 had the highest diversity of the four sites sampled in 2009-

2010. This site is closest to the open coast and likely receives drift from a large area of the lower

Narragansett Bay and open ocean sites. Pier 5 also has an abundance of hard substrata available for algal attachment, unlike the other three field sites.

Contrary to our expectations, we did not find a strict pattern of high diversity ( $\left.\mathrm{H}^{\prime}\right)$ at non-

bloom sites vs. low diversity at bloom-impacted sites, as Chepiwanoxet had the second highest

291 diversity of the four sites. This is particularly perplexing in light of environmental measurements 
292 (dissolved oxygen, water residence time; Granger et al., 2000) that indicate Chepiwanoxet is the

293 most eutrophic of the four sites. Since the algae sampled at all sites was largely drift, it is unclear

294 whether the diversity observed at Chepiwanoxet is representative of the site itself, or if

295 circulation patterns deposit a wide diversity of species from adjacent areas. However, all areas

296 within close proximity to Chepiwanoxet are also bloom-impacted, suggesting that the diversity

297 observed at this site is truly representative of the bloom-impacted community. Furthermore,

298 Chepiwanoxet had the highest evenness of the four sites sampled from 2009-2010, which differs

299 from general patterns that indicate eutrophication has a larger negative impact on evenness than

300 species richness (Hillebrand et al., 2007). Similar results were found in subestuaries of Waquoit

301 Bay, Massachusetts, USA, where macroalgal bloom biomass (Cladophora vagabunda and

302 Gracilaria tikvahiae) was linked to nutrient enrichment, while species richness was not (Fox et

303 al., 2008).

304

305

\subsection{Narragansett Bay blooms compared to Ulva blooms around the world}

306 To our knowledge, this is the first report of Ulva bloom biomass that has extensively

307 examined the relative contribution of cryptically co-occurring distromatic blade species

308 following molecular confirmation of the Ulva species present within an area (Guidone et al.,

309 unpublished data). We are unaware of any previous estimates of $U$. compressa bloom biomass,

310 but reports of Ulva bloom biomass based solely on morphology have identified U. rigida as the

311 causative species of blooms in Europe (Sfriso et al., 1992; Coat et al., 1998; Balducci et al.,

312 2001; Merceron and Morand, 2004 as U. armoricana) and the Philippines (Largo et al., 2004 as

313 U. armoricana). Ulva lactuca has been reported to bloom in North America (Lyons et al., 2009),

314 New Zealand (Park, 1992), and South Africa (Anderson et al., 1996). The density of 
315 Narragansett Bay blooms fall within the range of densities reported for most blooms of $U$. rigida

316 and $U$. lactuca $\left(150-3,000 \mathrm{~g} / \mathrm{m}^{2}\right.$ wet mass). One notable exception to this range is the bloom of

317 U. rigida in the Venice Lagoon, Italy, reported to have a biomass range of $5-20 \mathrm{~kg} / \mathrm{m}^{2}$ wet mass

318 (Schramm, 1999).

319 Given the difficulty in identifying Ulva species using morphology alone, and based on

320 our observation that $U$. rigida and $U$. compressa often bloom simultaneously, it is likely that

321 some prior reports of Ulva blooms have either misidentified the Ulva species involved or

322 underestimated the number of species present within the bloom. For example, a recent molecular

323 survey of Ulva in New Zealand found U. lactuca to be present at only 3 out of 195 sampled sites

324 (Heesch et al., 2009), indicating that New Zealand blooms are likely formed by another, more

325 abundant Ulva species. Additionally, based on a small sampling of Ulva blades within blooms in

326 Brittany, France, Merceron and Morand (2004) tentatively identified three co-occurring ulvoid

327 species (U. rigida as U. armoricana, U. rotundata, and Umbraulva olivascens as U. olivascens).

328 Unfortunately, even when armed with molecularly verified species descriptions, if morphological

329 features cannot be found to separate co-occurring species, detailed surveys of Ulva bloom

330 diversity such as we conducted will be challenging.

331

332 5. Acknowledgements

333 We would like to thank C. Blewett, J. Bonamusa, K. Eldredge, L. Falconer, M. Gennazio,

334 A. Heinze, K. Hyman, B. Konkle, M. O’Brien, C. Newton, B. Pestone, S. Rinehart, N. Rohr, T.

335 Schollmeier, E. Vincent, M. Wands, and A. Ziegler for help with field collections and biomass

336 processing. We would also like to thank C. Newton and two anonymous reviewers for their

337 evaluation of earlier versions of this manuscript. Funding for this research was provided by Bay 
338 Window (NOAA), the Rhode Island Natural History Survey, Rhode Island Sea Grant, the

339 Sounds Conservancy Quebec-Labrador Foundation, and the University of Rhode Island. This

340 material is based, in part, upon work supported in part by the National Science Foundation

341 EPSCoR Cooperative Agreement \#EPS-1004057 and the State of Rhode Island.

342

343

\section{References}

344 Anderson, R.J., Monteiro, P.M.S., Levitt, G.J., 1996. The effect of localised eutrophication on competition between Ulva lactuca (Ulvaceae, Chlorophyta) and a commercial resource of Gracilaria verrucosa (Gracilariaceae, Rhodophyta). Hydrobiologia 326/327, 291-296.

Balducci, C., Sfriso, A., Pavoni, B., 2001. Macrofauna impact on Ulva rigida C. Ag. production and the relationship with environmental variables in the lagoon of Venice. Mar. Environ. Res. 52, 27-49.

Berezina, N.A., Tsiplenkina, I.G., Pankova, E.S, Gubelit, J.I., 2007. Dynamics of invertebrate communities on the stony littoral of the Neva Estuary (Baltic Sea) under macroalgal blooms and bioinvasions. Transitional Waters Bulletin 1, 65-76.

Blomster, J., Bäck, S., Fewer, D.P., Kiirikki, M., Lehvo, A., Maggs, C.A., Stanhope,

Blomster, J., Maggs, C.A., Stanhope, M.J., 1999. Extensive intraspecific molecular analysis. J. Phycol. 35, 575-586.

360 Calabretta, C.J., Oviatt, C.A., 2008. The response of benthic macrofauna to 
361

362

363

364

365

366

367

368

369

370

371

372

373

374

375

376

377

378

379

380

381

382

383

anthropogenic stress in Narragansett Bay, Rhode Island: a review of human stressors and assessment of community conditions. Mar. Pollut. Bull. 56, 1680-1695.

Coat, G., Dion, P., Noailles, M.-C., de Reviers, B., Fontaine, J.-M., Berger-Perrot, Y., Loiseaux-de Goér, S., 1998. Ulva armoricana (Ulvales, Chlorophyta) from the coasts of Brittany (France). II. Nuclear rDNA ITS sequence analysis. Eur. J. Phycol. 33, 81-86.

Cohen, R.A., Fong, P., 2004. Physiological responses of a bloom-forming green macroalga to short-term change in salinity, nutrients, and light help explain its ecological success. Estuaries 27, 209-216.

Deacutis, C., 2008. Evidence of ecological impacts from excess nutrients in upper Narragansett Bay, In: Desbonnet, A., Costa-Pierce, B.A. (Eds.), Science for EcosystemBased Management. Springer, New York, pp. 349-381.

Deacutis, C., Murray, D., Prell, W., Saarman, E., Korhun, L., 2006. Hypoxia in the upper half of Narragansett Bay, RI, during August 2001 and 2002. Northeast. Nat. 13, 173-198.

Eklund, B., Svensson, A.P., Jonsson, C., Malm, T., 2005. Toxic effects of decomposing red algae on littoral organisms. Estuar. Coast. Shelf S. 62, 621-626.

Fletcher, R.L., 1996. The occurrence of green tides -- a review, In: Schramm, W., Niehuis, P.K. (Eds.), Marine benthic vegetation: recent changes and the effects of eutrophication. Springer, Berlin, pp. 7-43.

Fox, S.E., Stieve, E., Valiela, I., Hauxwell, J., McClelland, J., 2008. Macrophyte abundance in Waquoit Bay: effects of land-derived nitrogen loads on seasonal and multiyear biomass patterns. Estuar. Coast. 31, 532-541.

Gao, S., Chen, X., Yi, Q., Wang, G., Pan, G., Lin, A., Peng, G., 2010. A strategy for 
384

385

386

387

388

389

390

391

392

393

394

395

396

397

398

399

400

401

402

403

404

405

406

the proliferation of Ulva prolifera, main causative species of green tides, with formation of sporangia by fragmentation. PLoS ONE 5, e8571.

Granger, S.L., Mark, J., Buckley, B.A., Schwartz, M., 2000. An assessment of eutrophication in Greenwich Bay. Rhode Island Sea Grant, Narragansett.

Hauxwell, J., Cebrián, J., Furlong, C., Valiela, I., 2001. Macroalgal canopies contribute to eelgrass (Zostera marina) decline in temperate estuarine ecosystems. Ecology 82, 1007-1022.

Hauxwell, J., McClelland, J., Behr, P.J., Valiela, I., 1998. Relative importance of grazing and nutrient controls of macroalgal biomass in three temperate shallow estuaries. Estuaries 21, 347-360.

Hayden, H.S., Blomster, J., Maggs, C.A., Silva, P.C., Stanhope, M.J., Waaland, J.R., 2003. Linnaeus was right all along: Ulva and Enteromorpha are not distinct genera. Eur. J. Phycol. 38, 277-294.

Heesch, S., Broom, J.E.S., Neill, K.F., Farr, T.J., Dalen, J.L., Nelson, W.A., 2009. Ulva, Umbraulva, and Gemina: genetic survey of New Zealand taxa reveals diversity and introduced species. Eur. J. Phycol. 44, 143-154.

Hein, M., Pedersen, M.F., Sand-Jensen, K., 1995. Size dependent nitrogen uptake in micro- and macroalgae. Mar. Ecol. Prog. Ser. 118, 247-253.

Hillebrand, H., Gruner, D.S., Borer, E.T., Bracken, M.E.S., Cleland, E.E., Elser, J.J., Harpole, W.S., Ngai, J.T., Seabloom, E.W., Shurin, J.B., Smith, J.E., 2007. Consumer versus resource control of producer diversity depends on ecosystem type and producer community structure. P. Natl. Acad. Sci. 104, 10904-10909.

Hofmann, L.C., Nettleton, J.C., Neefus, C.D., Mathieson, A.C., 2010. Cryptic 
diversity of Ulva (Ulvales, Chlorophyta) in the Great Bay Estuarine System (Atlantic USA): introduced and indigenous distromatic species. Eur. J. Phycol. 45, 230-239.

Kim, J.-H., Kang, E.J., Park, M.G., Lee, B.-G., Kim, K.Y., 2011. Effects of temperature and irradiance on photosynthesis and growth of a green-tide-forming species (Ulva linza) in the Yellow Sea. J. App. Phycol. 23, 421-432.

Kraft, L.G.K., Kraft, G.T., Waller, R.F., 2010. Investigations in southern Australian Ulva (Ulvophyceae, Chlorophyta) taxonomy and molecular phylogeny indicate both cosmopolitanism and endemic cryptic species. J. Phycol. 46, 1257-1277.

Largo, D.B., Sembrano, J., Hiraoka, M., Ohno, M., 2004. Taxonomic and ecological profile of 'green tide' species of Ulva (Ulvales, Chlorophyta) in central Philippines. Hydrobiologia 512, 247-253.

Lee, V., Olsen, S., 1985. Eutrophication and management initiatives for the control of nutrient inputs to Rhode Island coastal lagoons. Estuaries 8, 191-202.

Leliaert, F., Zhang, X., Ye, N., Malta, E., Engelen, A., Mineur, F., Verbruggen, H., De Clerck, O., 2009. Research note: Identity of the Qingdao algal bloom. Phycol. Res. 57, $147-151$

Leskinen, E., Alström-Rapaport, C., Pamilo, P., 2004. Phylogeographical structure, distribution and genetic variation of the green algae Ulva intestinalis and U. compressa (Chlorophyta) in the Baltic Sea area. Mol. Ecol. 13, 2257-2265.

Littler, M.M., Littler, D.S., 1980. The evolution of thallus form and survival strategies in benthic marine macroalgae: field and laboratory tests of a functional form model. Am. Nat. 116, 25-44.

Liu, D., Keesing, J.K., Dong, Z., Zhen, Y., Di, B., Shi, Y., Fearns, P., Shi, P., 2010. 
430

431

432

433

434

435

436

437

438

439

440

441

442

443

444

445

446

447

448

449

450

451

Recurrence of the world's largest green-tide in 2009 in Yellow Sea, China: Porphyra yezoensis aquaculture rafts confirmed as nursery for macroalgal blooms. Mar. Pollut. Bull. 60, 1423-1432.

Lotze, H., Worm, B., Sommer, U., 2000. Propagule banks, herbivory and nutrient supply control population development and dominance patterns in macroalgal blooms. Oikos 89, 46-58.

Lotze, H.K., Worm, B., 2000. Variable and complementary effects of herbivores on different life stages of bloom-forming macroalgae. Mar. Ecol. Prog. Ser. 200, 167-175.

Lyons, P., Thornber, C., Portnoy, J., Gwilliam, E., 2009. Dynamics of macroalgal blooms along the Cape Cod National Seashore. Northeast. Nat. 16, 53-66.

Merceron, M., Morand, P., 2004. Existence of a deep subtidal stock of drifting Ulva in relation to intertidal algal mat developments. J. Sea Res. 52, 269-280.

Morand, P., Merceron, M., 2005. Macroalgal population and sustainability. J. Coast. Res. 21, 1009-1020.

Nelson, T.A., Haberlin, K., Nelson, A.V., Ribarich, H., Hotchkiss, R., Van Alstyne, K.L., Buckingham, L., Simunds, D.J., Fredrickson, K., 2008. Ecological and physiological controls of species composition in green macroalgal blooms. Ecology 89, 1287-1298.

Nelson, T.A., Lee, D.J., Smith, B.C., 2003a. Are "green tides" harmful algal blooms? Toxic properties of water-soluble extracts from two bloom-forming macroalgae, Ulva fenestrata and Ulvaria obscura (Ulvophyceae). J. Phycol. 39, 874-879.

Nelson, T.A., Nelson, A.V., Tjoelker, M., 2003b. Seasonal and spatial patterns of "green tides" 
452

453

454

455

456

457

458

459

460

461

462

463

464

465

466

467

468

469

470

471

472

473

474

(ulvoid algal blooms) and related water quality parameters in the coastal waters of Washington State, USA. Bot. Mar. 46, 263-275.

Oczkowski, A., Nixon, S., Henry, K., DiMilla, P., Pilson, M., Granger, S., Buckley, B., Thornber, C., McKinney R., Chaves, J., 2008. Distribution and trophic importance of anthropogenic nitrogen in Narragansett Bay: an assessment using stable isotopes. Estuar. Coast. 31, 53-69.

Park, S., 1992. Ulva lactuca monitoring programme. Bay of Plenty Regional Council, Tech. Rep. 32.

Pedersen, M.F., Borum, J., 1996. Nutrient control of algal growth in estuarine waters. Nutrient limitation and the importance of nitrogen requirements and nitrogen storage among phytoplankton and species of macroalgae. Mar. Ecol. Prog. Ser. 142, 261-272.

Raffaelli, D., Raven, J.A., Poole, L.A., 1998. Ecological impact of green macroalgal blooms. Oceanogr. Mar. Biol. 36, 97-125.

Rivers, J.S., Peckol, P., 1995. Summer decline of Ulva lactuca (Chlorophyta) in a eutrophic embayment: interactive effects of temperature and nitrogen availability? J. Phycol 31, 223-228.

Schramm, W., 1999. Factors influencing seaweed responses to eutrophication: some results from EU-project EUMAC. J. App. Phycol. 11, 69-78.

Sfriso, A., Pavoni, B., Marcomini, A., Orio, A.A., 1992. Macroalgae, nutrient cycles, and pollutants in the Lagoon of Venice. Estuar. Coast. 15(4), 517-528.

Sousa, A.I., Martins, I., Lillebø, A.I., Flindt, M.R., Pardal, M.A., 2007. Influence of salinity, nutrients and light on the germination and growth of Enteromorpha sp. spores. J. Exp. Mar. Biol. Ecol. 341, 142-150. 
475 Tan, I.H., Blomster, J., Hansen, G., Leskinen, E., Maggs, C.A., Mann, D.G., Sluiman,

476

477

478

479

480

481

482

483

484

485

486

487

488

489

490

491

492

493

494

495

496

497

H.J., Stanhope, M.J., 1999. Molecular phylogenetic evidence for a reversible morphogenetic switch controlling the gross morphology of two common genera of green seaweeds, Ulva and Enteromorpha. Mol. Biol. Evol. 16, 1011-1018.

Taylor, R., Fletcher, R.L., Raven, J.A., 2001. Preliminary studies on the growth of selected 'green tide' algae in laboratory culture: effects of irradiance, temperature, salinity and nutrients on growth rate. Bot. Mar. 44, 327-336.

Thomsen, M., McGlathery, K., 2006. Effects of accumulations of sediments and drift algae on recruitment of sessile organisms associated with oyster reefs. J. Exp. Mar. Biol. Ecol. 328, 22-34.

Underwood, A.J., 1997. Experiments in ecology. Cambridge University Press, Cambridge.

Valiela, I., McClelland, J., Hauxwell, J., Behr, P.J., Hersh, D., Foreman, K., 1997. Macroalgal blooms in shallow estuaries: controls and ecophysiological and ecosystem consequences. Limnol. Oceanogr. 42, 1105-1118.

Van Alstyne, K.L., Nelson, A.V., Vyvyan, J.R., Cancilla, D.A., 2006. Dopamine functions as an antiherbivore defense in the temperate green alga Ulvaria obscura. Oecologia 148, 304-311.

Worm, B., Lotze, H.K., 2006. Effects of eutrophication, grazing, and algal blooms on rocky shores. Limnol. Oceanogr. 51, 569-579.

Ye, N.-H., Zhang, X.-W., Mao, Y.-Z., Liang, C.-W., Xu, D., Zou, J., Zhuang, Z.-M., Wang, Q.-Y., 2011. 'Green tides' are overwhelming the coastline of our blue planet: taking the world's largest example. Ecol. Res. 26, 477-485.

Yokoyama, H., Ishihi, Y., 2010. Bioindicator and biofilter function of Ulva spp. 
503 Figure 1 Map of Rhode Island, USA, showing the location of our four study sites.

504

505 Figure 2 Ulva biomass during the May-September 2009 and February and May 2010 surveys at 506 A) Pier 5 and B) GSO. Error bars are \pm 1 SE.

507

508 Figure 3 Ulva biomass at the two bloom-impacted sites A) Chepiwanoxet and B) Brushneck

509 Cove. Error bars are \pm 1 SE.

510

511 Figure 4 Algal percent cover at all sites during 2009-2010. Species comprising less than 10\%

512 cover in all months are not shown. Site abbreviations follow Table 2. ACGP refers to mixed mats

513 of Agardhiella subulata, Ceramium virgatum, Gracilaria spp., and Polysiphonia spp. * indicates 514 no sampling due to ice cover.

515

516 Figure 5 Algal percent cover at bloom-impacted sites during 2010-2011. Species comprising

517 less than $4 \%$ cover in all months are not shown. Site abbreviations follow Table 2. ACGP refers

518 to mixed mats of Agardhiella subulata, Ceramium virgatum, Gracilaria spp., and Polysiphonia

519 spp. * indicates no sampling due to storm surge.

520 
521 Table 1. Results of a nested ANOVA on Ulva biomass among month-year, site, transect nested

522 within site, and species for a) all study sites from 2009-2010, and b) Brushneck Cove and

523 Chepiwanoxet from 2010-2011.

524

$525 \quad$ (a)

\begin{tabular}{lrrrc}
\hline Source & df & \multicolumn{1}{c}{ MS } & \multicolumn{1}{c}{ F } & P \\
\hline Month-Year & 6 & $6,267.02$ & 19.19 & $<0.0001$ \\
Site & 3 & $24,238.75$ & 74.21 & $<0.0001$ \\
Transect[Site] & 4 & 109.38 & 0.33 & 0.85 \\
Species & 3 & $8,006.74$ & 24.51 & $<0.0001$ \\
Month-Year*Site & 18 & $4,348.83$ & 13.31 & $<0.0001$ \\
Month-Year*Transect[Site] & 24 & $2,202.50$ & 6.74 & $<0.0001$ \\
Month-Year*Species & 18 & $3,645.81$ & 11.16 & $<0.0001$ \\
Site*Species & 9 & $5,645.93$ & 17.28 & $<0.0001$ \\
Transect[Site]*Species & 12 & 650.59 & 1.99 & 0.0217 \\
Month-Year*Site*Species & 54 & $3,210.02$ & 9.83 & $<0.0001$ \\
Month-Year*Transect[Site]*Species & 72 & $1,107.17$ & 3.39 & $<0.0001$ \\
Error & 1,624 & 326.65 & & \\
\hline
\end{tabular}

(b)

\begin{tabular}{lrrrc}
\hline Source & df & MS & \multicolumn{1}{c}{ F } & \multicolumn{1}{c}{ p } \\
\hline Month-Year & 15 & $12,946.93$ & 30.22 & $<0.0001$ \\
Site & 1 & 6.79 & 0.016 & 0.90 \\
Transect[Site] & 2 & $6,889.20$ & 16.08 & $<0.0001$ \\
Species & 3 & $44,216.10$ & 103.20 & $<0.0001$ \\
Month-Year*Site & 15 & 721.90 & 1.68 & 0.048 \\
Month-Year*Transect[Site] & 30 & $5,333.94$ & 12.45 & $<0.0001$ \\
Month-Year*Species & 45 & $8,984.53$ & 20.97 & $<0.0001$ \\
Site*Species & 3 & $8,087.41$ & 18.88 & $<0.0001$ \\
Transect[Site]*Species & 6 & $4,578.26$ & 10.69 & 0.0013 \\
Month-Year*Site*Species & 45 & $2,230.41$ & 5.21 & $<0.0001$ \\
Month-Year*Transect[Site]*Species & 90 & $4,134.88$ & 9.65 & $<0.0001$ \\
Error & 1227 & 428.47 & & \\
\hline
\end{tabular}


528

Table 2. Taxa observed during our 2009-2010 field surveys. Site abbreviations are: P Pier 5, G GSO, C Chepiwanoxet, and B

Brushneck Cove. Genera marked with an asterisk require microscopic examination for species determinations.

\begin{tabular}{|c|c|c|c|c|c|c|c|c|}
\hline & \multicolumn{6}{|c|}{2009} & \multicolumn{2}{|c|}{2010} \\
\hline & May & \multicolumn{2}{|r|}{ June } & July & August & September & February & May \\
\hline & $P G C B$ & $\mathrm{P}$ & $\mathrm{G} \mathrm{C} \mathrm{B}$ & $P G C B$ & $P G C B$ & $\mathrm{P} G \mathrm{CB}$ & $\mathrm{P} G \mathrm{CB}$ & $P G C B$ \\
\hline Ulva blades & X X X X & $\mathrm{X}$ & X X & X X X X & X X X X & X X & X X & X X X X \\
\hline Ulva tubes & $X X X X$ & $\mathrm{X}$ & X X & X X X & X X X & $X$ & $\mathrm{X}$ & X X X \\
\hline $\begin{array}{l}\text { Agardhiella } \\
\text { subulata }\end{array}$ & & & & $X$ & $X$ & $X$ & X X & $X$ \\
\hline $\begin{array}{l}\text { Ahnfeltia } \\
\text { plicata }\end{array}$ & & & & & & & $X$ & \\
\hline $\begin{array}{l}\text { Ascophyllum } \\
\text { nodosum }\end{array}$ & $X$ & $\mathrm{X}$ & & $\mathrm{X}$ & $X$ & $X$ & $X$ & $\mathrm{X}$ \\
\hline $\begin{array}{l}\text { Bonnemaisonia } \\
\text { hamifera }\end{array}$ & & $X$ & & X X & & & & $X$ \\
\hline $\begin{array}{l}\text { Bryopsis } \\
\text { plumosa }\end{array}$ & & & & $\mathrm{X}$ & $X$ & & & \\
\hline $\begin{array}{l}\text { Ceramium } \\
\text { virgatum }\end{array}$ & $\mathrm{X} X \mathrm{X} X$ & $\mathrm{X}$ & $\mathrm{X}$ & X X & $\mathrm{X}$ & X X & $\mathrm{X}$ & X X X X \\
\hline $\begin{array}{l}\text { Chaetomorpha } \\
\text { spp.* }\end{array}$ & & & & X X & $X$ & & & \\
\hline $\begin{array}{l}\text { Champia } \\
\text { parvula }\end{array}$ & & & & X X & & & & \\
\hline $\begin{array}{l}\text { Chondrus } \\
\text { crispus }\end{array}$ & $\mathrm{X} \mathrm{X}$ & $\mathrm{X}$ & & X X & X X & $X$ & X X & X X \\
\hline $\begin{array}{l}\text { Codium fragile } \\
\text { ssp. fragile }\end{array}$ & $X$ & & & X X & $X$ & $X$ & X X & $\mathrm{X}$ \\
\hline $\begin{array}{l}\text { Corallina } \\
\text { officinalis }\end{array}$ & & & & & & & $X$ & \\
\hline
\end{tabular}




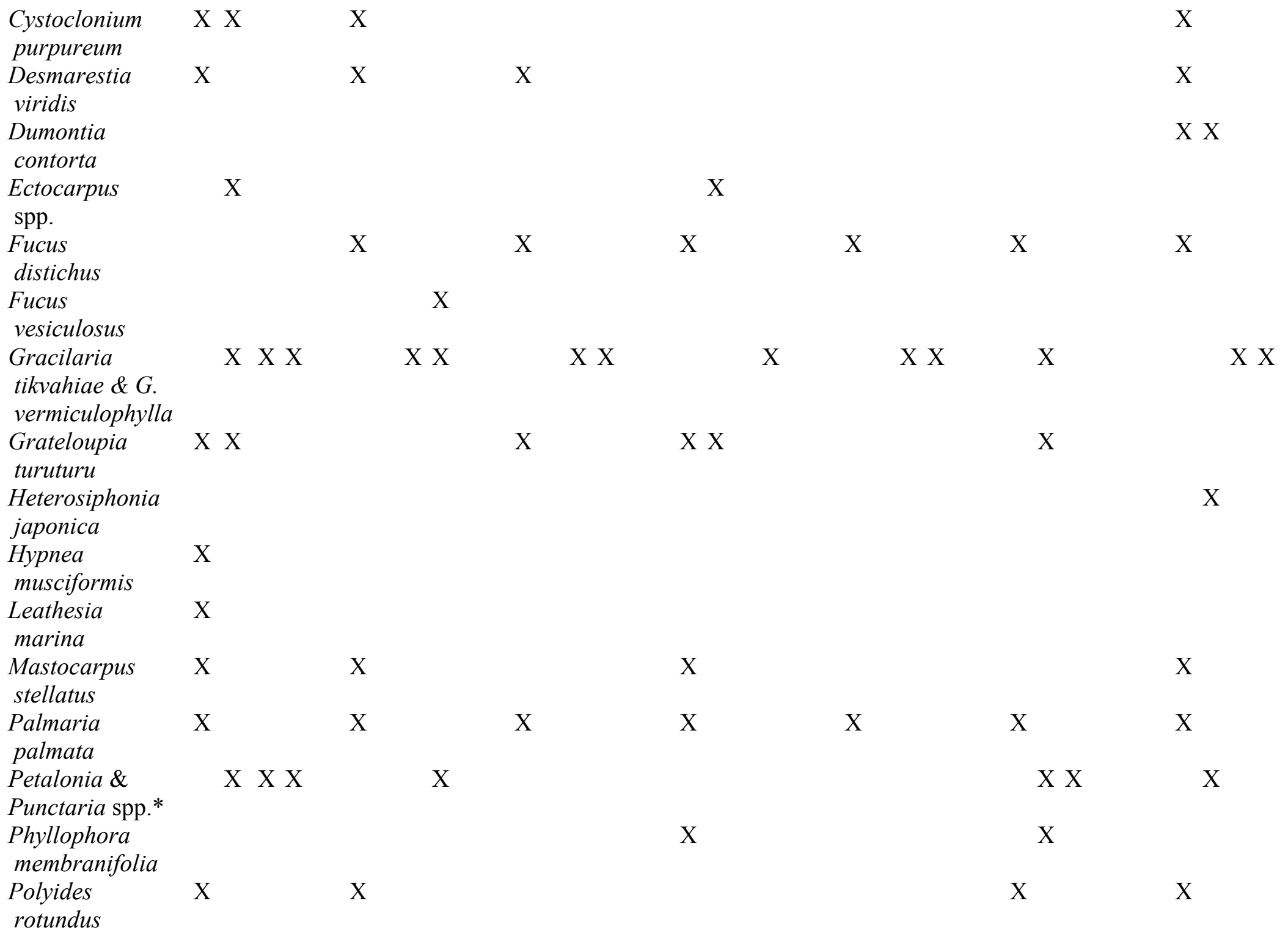




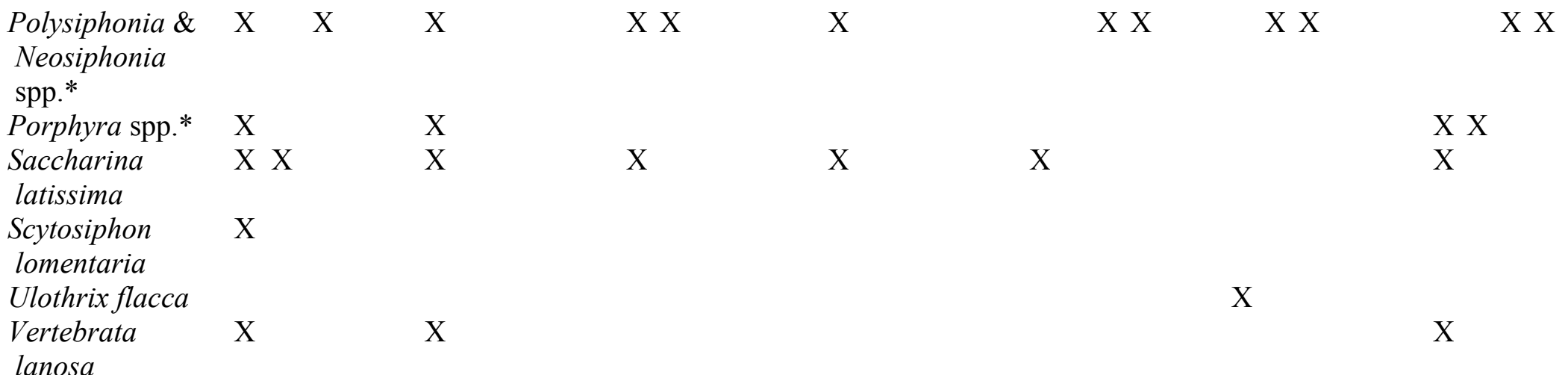


530 Table 3. Average species richness (S), Pielou's evenness (J'), and Shannon diversity index (H')

531 for our 2009-2010 and 2010-2011 field surveys.

532

533

\begin{tabular}{lllll}
\hline Survey & Site & S & J' & H' \\
\hline $2009-2010$ & Brushneck Cove & 1.56 & 0.34 & 0.12 \\
& Chepiwanoxet & 2.92 & 0.76 & 0.76 \\
& GSO & 1.45 & 0.72 & 0.33 \\
$2010-2011$ & Pier 5 & 4.45 & 0.68 & 0.92 \\
& Brushneck Cove & 1.81 & 0.67 & 0.33 \\
& Chepiwanoxet & 2.38 & 0.60 & 0.52 \\
\hline
\end{tabular}

534 
535 Table 4. Results from a two-way crossed ANOSIM for differences amongst sites and months in

536 our 2009-2010 survey. R-values close to 1.00 indicate complete separation between groups while

537 R-values close to 0 indicate little separation between groups. All pairwise tests were significant

$538(\mathrm{p}=0.001)$. (a) Tests for differences between site groups across all month groups. (b) Tests for

539 differences between month groups across all site groups.

540

$541 \quad$ (a)

\begin{tabular}{lllll}
\hline Global R: 0.760 & Brushneck Cove & Chepiwanoxet & GSO & Pier 5 \\
\hline Brushneck Cove & & & & \\
Chepiwanoxet & 0.736 & & & \\
GSO & 0.787 & 0.703 & & \\
Pier 5 & 0.908 & 0.830 & 0.766 & \\
\hline
\end{tabular}

(b)

\begin{tabular}{llllllll}
\hline Global R: 0.470 & $\begin{array}{l}\text { May } \\
2009\end{array}$ & June & July & August & September & $\begin{array}{l}\text { February } \\
2010\end{array}$ & May \\
\hline May 2009 & & & & & & & \\
June & 0.179 & & & & & & \\
July & 0.481 & 0.518 & & & & & \\
August & 0.413 & 0.515 & 0.162 & & & \\
September & 0.468 & 0.444 & 0.689 & 0.681 & & \\
February & 0.460 & 0.690 & 0.683 & 0.755 & 0.702 & \\
May 2010 & 0.215 & 0.379 & 0.560 & 0.565 & 0.558 & 0.256 & \\
\hline
\end{tabular}


543 Table 5. Results from a two-way crossed SIMPER analysis for average similarity and

544 dissimilarity amongst sites across all months in our 2009-2010 survey. ACGP refers to mats of

545 intertwined Agardhiella subulata, Ceramium virgatum, Gracilaria spp., and Polysiphonia spp.

546 Site abbreviations follow Table 2.

547

\begin{tabular}{|c|c|c|c|c|c|c|}
\hline \multirow{2}{*}{\multicolumn{3}{|c|}{ Within site similarity }} & \multicolumn{2}{|c|}{ Percent contribution } & \multicolumn{2}{|c|}{ Cumulative percent } \\
\hline \multirow{2}{*}{\multicolumn{7}{|c|}{$\begin{array}{l}\text { Within site similarity } \\
\text { Brushneck Cove- Average similarity: } 77.69\end{array}$}} \\
\hline & & & & & & \\
\hline \multicolumn{3}{|c|}{ Ulva blades } & \multicolumn{2}{|l|}{95.74} & \multicolumn{2}{|l|}{95.74} \\
\hline \multicolumn{7}{|c|}{ Chepiwanoxet - Average similarity: 65.76} \\
\hline \multicolumn{3}{|l|}{ Ulva tubes } & \multicolumn{2}{|l|}{34.73} & \multicolumn{2}{|l|}{34.73} \\
\hline \multicolumn{3}{|l|}{ Ulva blades } & \multicolumn{2}{|l|}{33.30} & \multicolumn{2}{|l|}{68.03} \\
\hline \multicolumn{3}{|l|}{ ACGP } & \multicolumn{2}{|l|}{20.71} & \multicolumn{2}{|l|}{88.74} \\
\hline \multicolumn{3}{|l|}{ Gracilaria spp. } & \multicolumn{2}{|l|}{5.47} & \multicolumn{2}{|l|}{94.21} \\
\hline \multicolumn{7}{|c|}{ GSO - Average similarity: 45.89} \\
\hline \multicolumn{3}{|l|}{ Ulva tubes } & \multicolumn{2}{|l|}{58.22} & \multicolumn{2}{|l|}{58.22} \\
\hline \multicolumn{3}{|l|}{ Polysiphonia spp. } & \multicolumn{2}{|l|}{13.72} & \multicolumn{2}{|l|}{71.95} \\
\hline Ceramium virgatum & & & \multicolumn{2}{|l|}{11.53} & 83.48 & \\
\hline Chondrus crispus & & & 7.68 & & 91.16 & \\
\hline Pier 5 - Average similarit & 54.19 & & & & & \\
\hline Chondrus crispus & & & 43.58 & & 43.58 & \\
\hline Saccharina latissima & & & 17.87 & & 61.45 & \\
\hline Ulva blades & & & 9.77 & & 71.22 & \\
\hline Palmaria palmata & & & 9.33 & & 80.55 & \\
\hline Ulva tubes & & & 6.21 & & 86.76 & \\
\hline Desmarestia viridis & & & 3.45 & & 90.21 & \\
\hline Between site dissimilarity & $\mathrm{Pel}$ & tage col & ation to a & ge dissin & arity be & en sites \\
\hline Taxon & $\mathrm{B}-\mathrm{C}$ & B-G & B-P & $\mathrm{C}-\mathrm{G}$ & C-P & G-P \\
\hline Ulva blades & 21.87 & 60.42 & 24.08 & 29.66 & 12.58 & 8.43 \\
\hline Ulva tubes & 32.11 & 15.82 & 9.57 & 22.95 & 14.15 & 8.62 \\
\hline ACGP & 24.52 & - & - & 14.94 & 10.24 & - \\
\hline Ascophyllum nodosum & - & - & - & - & - & 2.48 \\
\hline Ceramium virgatum & 6.10 & 5.39 & - & 8.15 & 2.80 & 3.63 \\
\hline Chondrus crispus & - & - & 20.65 & 4.33 & 17.73 & 30.73 \\
\hline $\begin{array}{l}\text { Codium fragile ssp. } \\
\text { fragile }\end{array}$ & - & - & - & - & 1.86 & - \\
\hline Desmarestia viridis & - & - & 2.86 & - & 3.17 & 4.20 \\
\hline Fucus spp. & - & - & 5.21 & - & 4.30 & 5.91 \\
\hline Gracilaria spp. & 9.72 & 8.01 & 4.31 & 7.86 & 4.89 & - \\
\hline Grateloupia turuturu & - & - & - & - & - & 1.50 \\
\hline Palmaria palmata & - & - & 8.31 & - & 5.58 & 7.63 \\
\hline
\end{tabular}


Polysiphonia spp.

Porphyra spp.

Saccharina latissima

Ulothrix flacca

Total contribution of species

Average between site dissimilarity

\begin{tabular}{llllll}
- & 5.14 & 4.53 & 4.62 & 3.65 & 2.49 \\
- & - & - & - & - & 2.20 \\
- & - & 10.81 & - & 7.84 & 15.75 \\
- & - & - & - & 2.68 & - \\
& & & & & \\
94.32 & 94.77 & 90.33 & 92.51 & 91.47 & 91.35 \\
57.16 & 92.68 & 85.55 & 82.62 & 83.83 & 87.21 \\
\hline
\end{tabular}


Figure 1

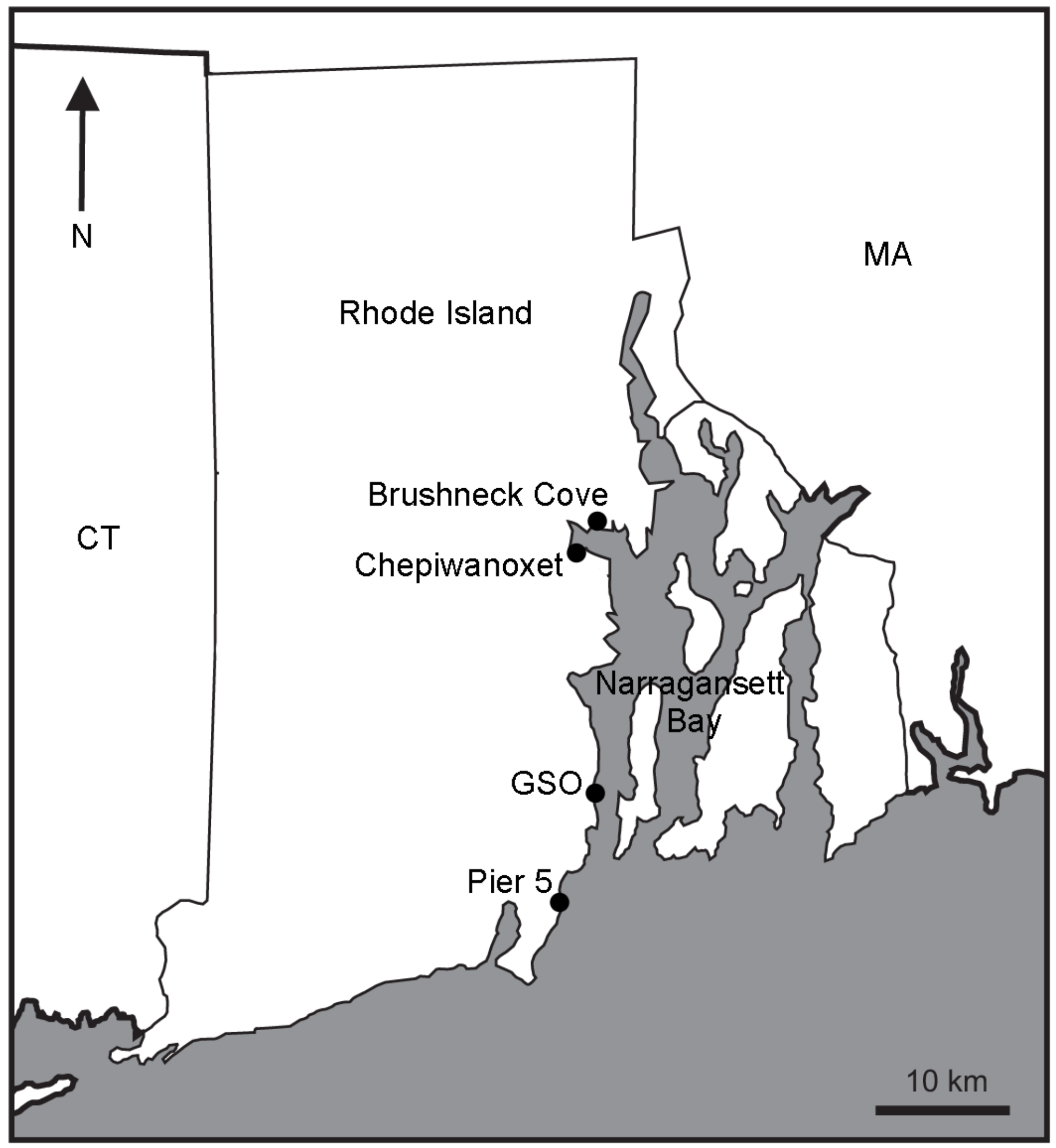




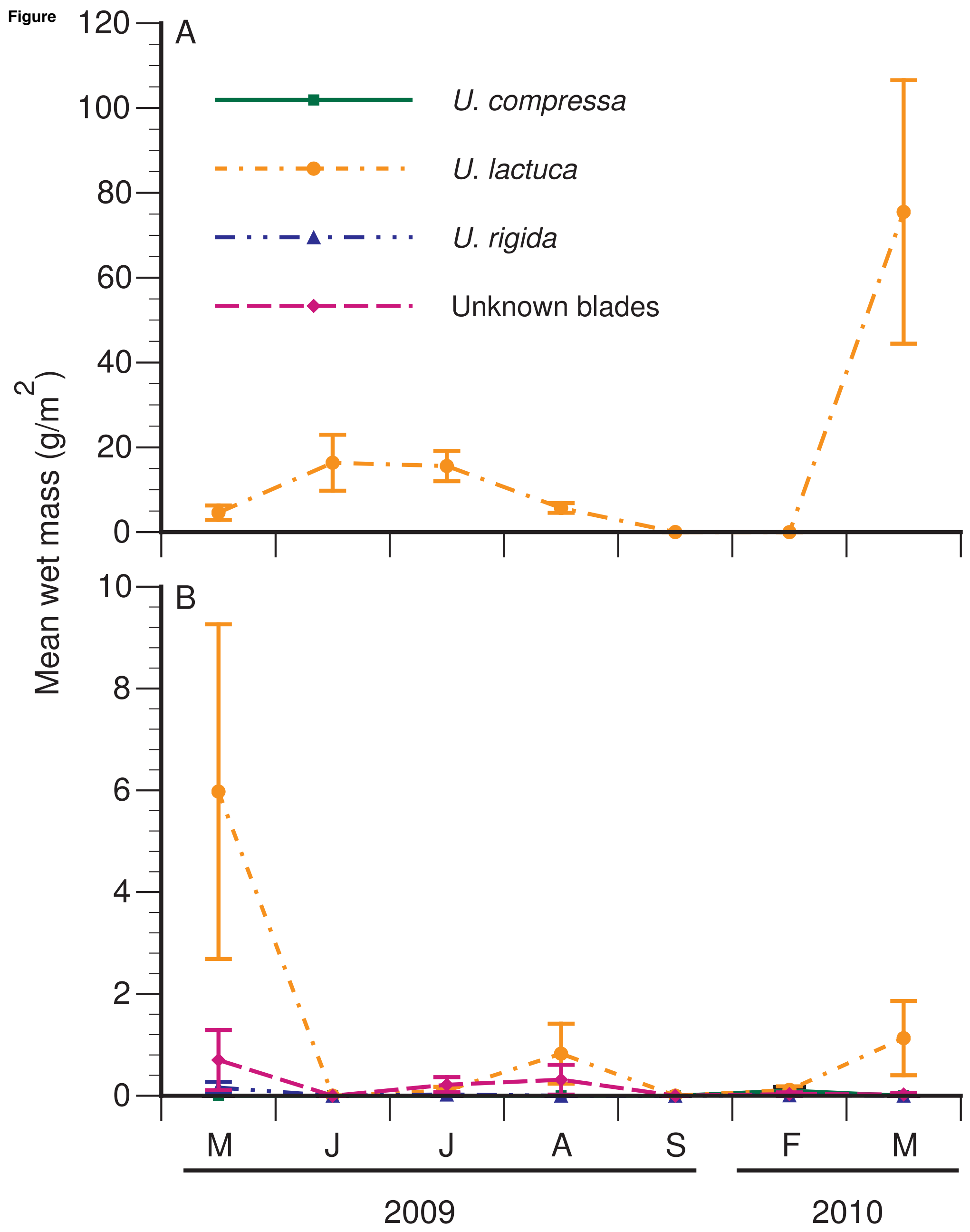


Figure

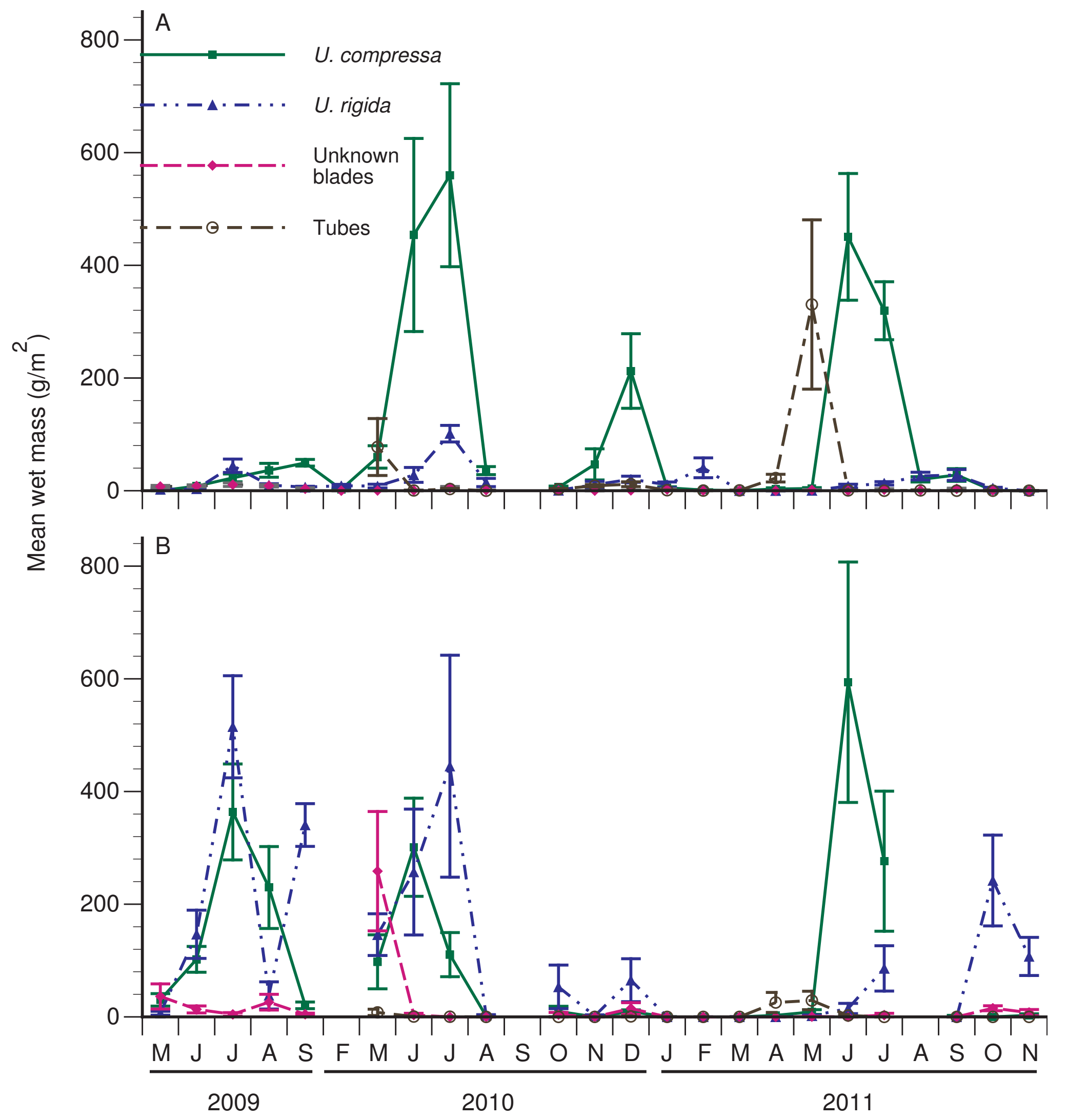


Figure

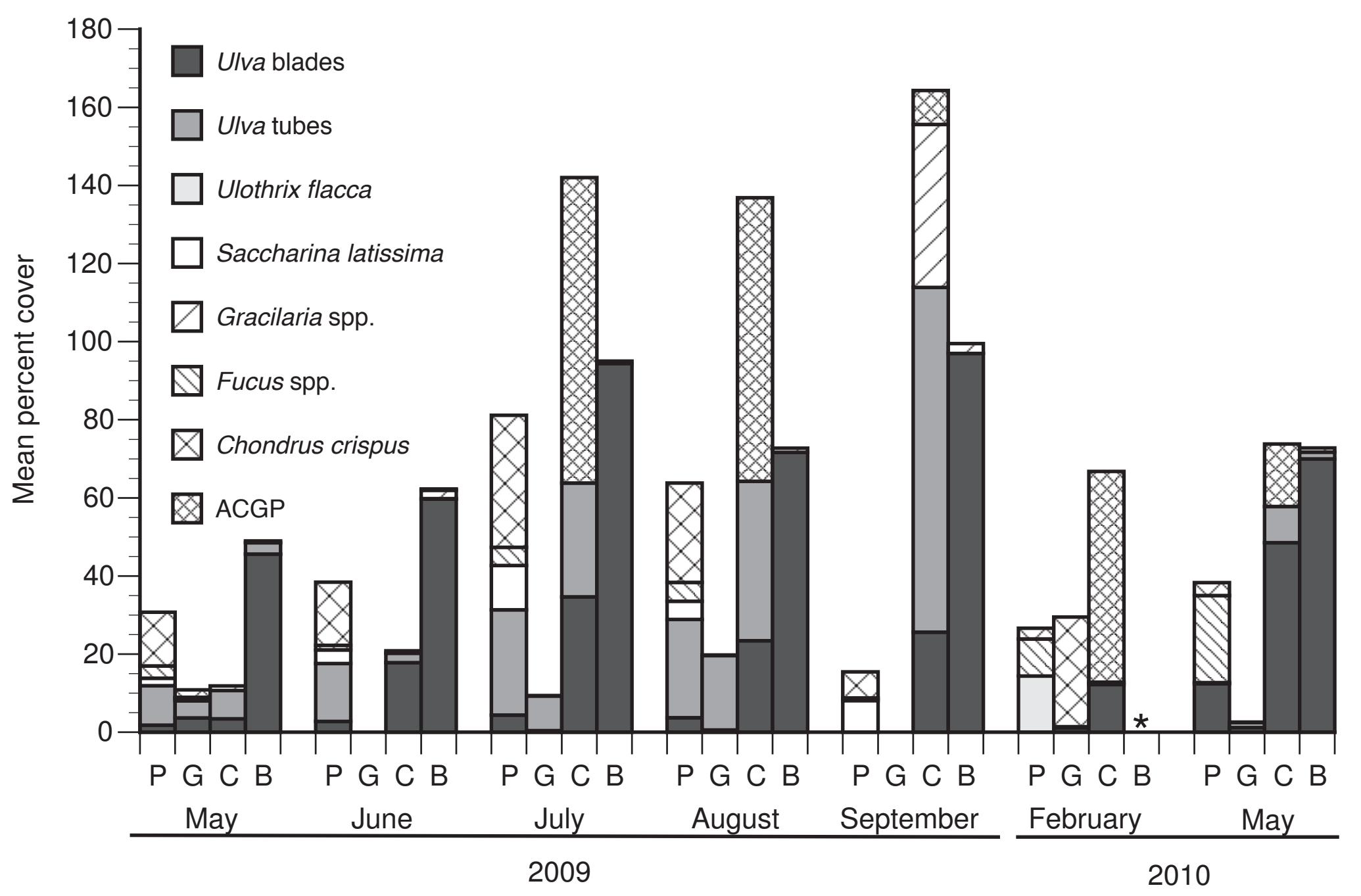


Figure

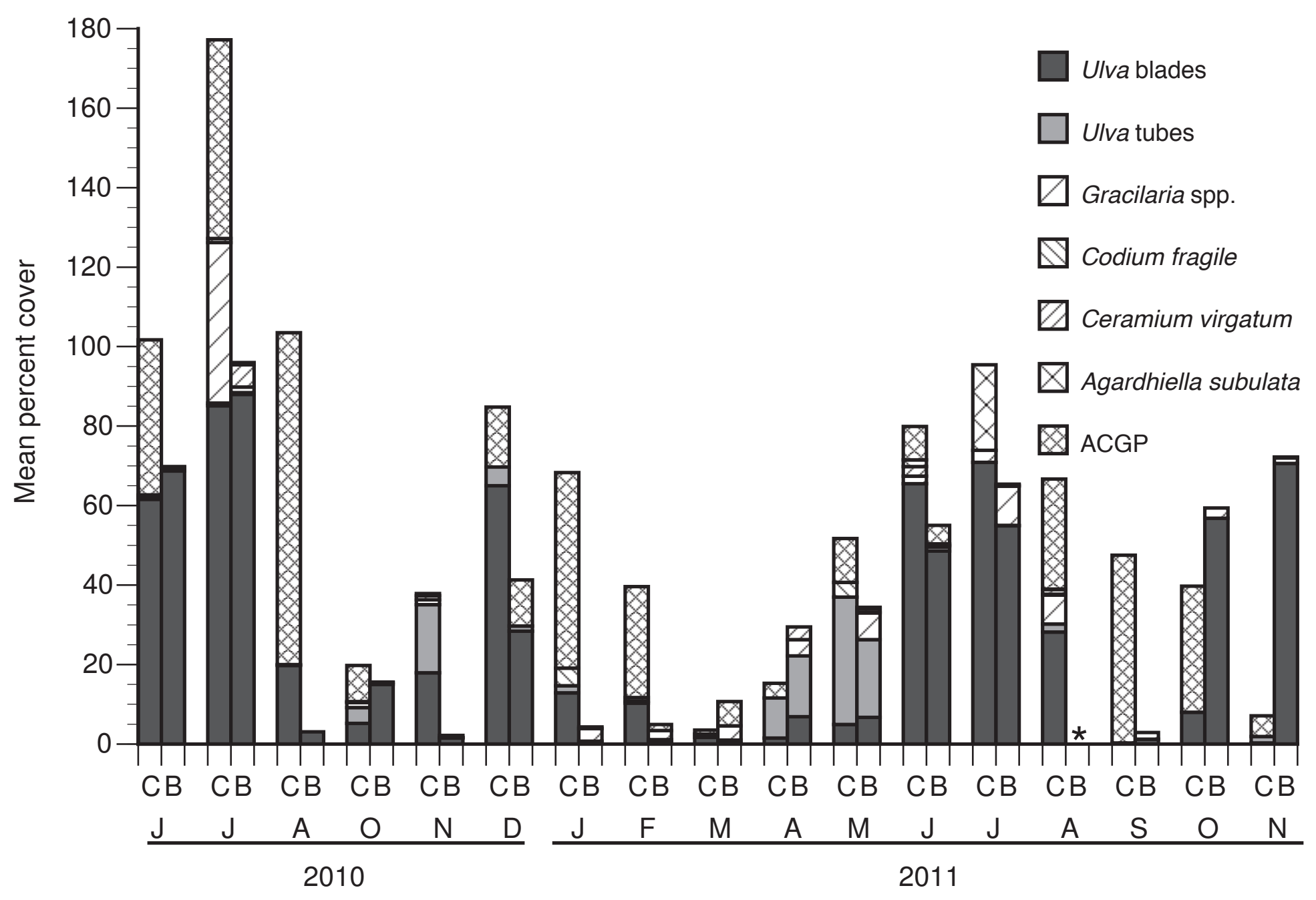

